\section{Journal of Global \\ Management Sciences}

Vol. 4, $\mathrm{N}^{\circ}$ 1, 2021

\title{
Social climate and professional competences in the Public Superior Pedagogical Institute of Huaraz [Clima social y competencias profesionales en el Instituto Superior Pedagógico Público de Huaraz]
}

\author{
Diómedes Sánchez Morenoa, José Yovera Saldarriaga ${ }^{\mathrm{b}}$, Jesús More Lópezb, \\ Ronald Rodriguez Espinoza ${ }^{\mathrm{c},{ }^{*}}$, Dante Cruz Nieto ${ }^{c}$, Héctor Castro Bartoloméc \\ alnstituto Superior Pedagógico Público de Huaraz, Peru \\ bUniversidad Nacional Santiago Antúnez de Mayolo, Peru \\ cUniversidad Nacional José Faustino Sánchez Carrión, Peru \\ *rrodriguez@unjfsc.edu.pe
}

Received: 30 December 2020; Accepted: 14 January 2021; Published: 20 January 2021

\section{Resumen}

El objetivo es demostrar la relación entre el clima social y el desarrollo de competencias profesionales en estudiantes de educación inicial del Instituto Superior Pedagógico Público de Huaraz durante el año 2018. El trabajo es no experimental, descriptivo correlacional. La población de estudio fue de 206 estudiantes, la muestra fue de 126. Los resultados acreditan que el Clima Social incide en el desarrollo de Competencias.

Palabras clave: Clima de aula, clima social, competencias.

\begin{abstract}
The objective is to demonstrate the relationship between the social climate and the development of professional skills in initial education students of the Higher Public Pedagogical Institute of Huaraz during 2018. The work is non-experimental, descriptive correlational. The study population was 206 students. The sample was 126. The results show that the Social Climate affects the development of Competences.
\end{abstract}

Keywords: Classroom climate, social climate, competitions.

\section{Introduction}

The study takes as background research works that provide the theoretical and methodological progress in the understanding and procedure of the study variables. Thus, Barrientos (2016) in his descriptive-correlational inquiry states that there is an association between interactive communication between classroom members and the teacher's ability to promote both formal and informal thinking and expression skills, creating discussions and executing various activities, seeking encourage learning, knowledge, thinking, and the acquisition of rich and varied vocabulary.

Márquez (2004) in his descriptive correlational study sought to determine the relationships between the "social climate", family and classroom, the perception of self-efficacy of young people 
Vol. 4, $\mathrm{N}^{\circ}$ 1, 2021

\section{GMS \\ Journal of Global Management Sciences}

Copyright @ 2021 , CINCADER.

ISSN 2663-0753

DOI: https://doi.org/10.32829/gms.v4i1.208
A publication of CINCADER

Centre of Research and Training for

Regional Development

Online at www.journals.cincader.org

and their "academic status". The results established that the dominance of the type of student in the academic status, influence of the time of stay in Spain in the academic status, in the sense of identity and belonging to the host culture.

Pereira (2010), examined the classroom climate in the university environment, conceiving that the participatory dynamics that are developed, establish a favorable environment or not, for the teaching and learning process, which must be estimated, if chosen by a comprehensive and quality education.

When examining the literature on climate in the school context, Cere (1993), conceives it as the set of psychosocial peculiarities of an educational center, determined by organized, personal and functional elements of the institution, which, integrated in a determined dynamic process, they grant a characteristic style to said center, conditioning, at the same time, of the different educational processes. In this regard, Ríos et al. (2010) think of it as a multidimensional construct; materially composed of furniture and infrastructure, and immaterial, by people, their peculiarities and the type of interaction they build in the classroom space, highlighting the interaction between the educator and the disciples and between them. It is understood, then, that the classroom climate can form a good classroom climate, for others not.

According to the aforementioned, it can be reflected that the classroom climate would be made up of the Relationships dimension, which would assess the level at which students are integrated in the class, collaborate with each other; by the Organization dimension, which reaches aspects allusive to the influence of the Directorate for the center's climate, domains of the formal structure for the center's climate, and the Growth dimension, related to the style of the teacher's work; motivation, perception of sources of annoyance or teacher tension.

With regard to professional competences in students, Mas (2011) defines competence as a polysemic, ambiguous term, with a variety of meanings and complex due to the components that compose it. In the study it is assumed that the competences are formed by Knowledge (knowing), skills (knowing how to do), attitudes and values (knowing how to be and be), developed through pedagogical simulations, with socio-labor experience.

These directions entail permutations in the role of teachers, thus Pavié (2011) alludes that demands are permanently addressed to the teacher's professional profile and that they are influenced by a context marked by the intercultural, the increase in the diversity of the students, a growing importance towards mastering different languages, the increasing increase in learning difficulties in scientific subjects or the insertion of new information technologies, etc. For his part, Tejada (2009) points out that, if we now focus on the alignment of competencies in the most strictly pedagogical field, the university teaching expert, in addition to being an expert in the corresponding academic discipline, must have a wide range of basic professional competencies, among which it alludes, the knowledge of the student's learning process in academic and natural contexts, the organization of teaching and didactic interaction, use of pertinent didactic methods and techniques, management of didactic interaction and relationships with the students, evaluation, control and organization of their own teaching and learning, knowledge of legal and institutional norms that regulate the rights and duties of the teacher and the student, management of their own professional development as a teacher and diagnosis and identification of needs and objectives innovation and improvement of their teaching and training.

The research is theoretically justified, because it is necessary to concentrate on the training of educators, foundations of socio-critical interculturality, social bilingualism, Morín's complex thinking, the learning management approach within the framework of continuous progress. These approaches will be enriched by conceiving the correlation between the classroom climate and professional skills; methodologically, the study will help the systematization of data with 


\section{GMS \\ Journal of Global Management Sciences}

Vol. 4, $\mathrm{N}^{\circ}$ 1, 2021
Copyright @ 2021, CINCADER.

ISSN 2663-0753

DOI: https://doi.org/10.32829/gms.v4i1.208

quantitative and qualitative instruments such as the Likert scale and systematic observation, to show the association of the two variables of the article. In the social sphere, it is necessary a comprehensive training that allows students a healthy climate in the classroom, our students face an uncertain society, with risk of digital divide; globalized, but with strong individualism, pragmatism, fascisms and fundamentalisms; welfare society, but with the danger of progressive compulsive consumerism.

Thus understood the reality in the theoretical and empirical, the following question is formulated: what is the relationship between the social climate in the classroom and the development of professional competences in initial education students at the Huaraz Public Pedagogical Higher Education Institute during the period 2018? At the same time, the following hypothesis is proposed: There is a significant relationship between the social climate in the classroom and the development of professional performance skills in students of the professional career of initial education; and as an objective to demonstrate the relationship between the social climate in the classroom and the development of professional performance competencies in students of the professional career of initial education.

\section{Materials and Methods}

The research is descriptive correlational. The population consisted of 206 students from the initial education professional career, the sample size was 126 students chosen by proportional stratified sampling. The technique used was the scale to measure attitudes, and the Likert grading formulated by Becerra, (2006) was used as an instrument, which consists of 56 items divided into: dimension relationships 21 items; organization 14 items; and growth 21 items. Likewise, for professional competences in initial education, the Likert scale questionnaire was used. On the development of professional competences of 44 items divided into: personal dimension 16 items; pedagogical professional 17 items, and socio-community dimension 11 items; both were validated by expert judgment. For statistical reliability, Cronbach's Alpha was applied.

The statistical process required descriptive and inferential statistics. For the hypothesis test, the Chi square test was used, which allowed us to assess the relationship of the variables, using the SPSS v. 21 software.

\section{Results}

The results are presented in tables that allow evaluating the behavior of the variables: Classroom climate and achievements of professional competence, then the relationship between them is presented to validate or not the hypothesis.

Table 1: Social climate in the classroom in students of the initial education professional career of the Higher Public Pedagogical Institute of Huaraz.

\begin{tabular}{lcc}
\hline & Students & Percentage \\
\hline Low & 21 & 16.7 \\
Medium & 84 & 66.7 \\
High & 21 & 16.7 \\
\hline Total & 126 & 100.0 \\
\hline
\end{tabular}




\section{Journal of Global Management Sciences}

Vol. 4, $\mathrm{N}^{\circ} 1,2021$

Copyright @ 2021, CINCADER.

ISSN 2663-0753

DOI: https://doi.org/10.32829/gms.v4i1.208

\section{CINCADER}

Centre of Research and Training for

Regional Development

Online at www.journals.cincader.org

Table 1 shows that the classroom climate is mostly at a medium to high level, which shows that the relationship between the protagonists of the pedagogical work in this institution is quite acceptable.

Table 2: Development of Professional Competences in students of the professional career of initial education of the Higher Public Pedagogical Institute of Huaraz.

\begin{tabular}{lcc}
\hline & Students & Percentage \\
\hline Low & 17 & 13.5 \\
Medium & 92 & 73.0 \\
High & 17 & 13.5 \\
\hline Total & 126 & 100.0 \\
\hline
\end{tabular}

Table 2 shows that the professional skills that the studied students have been achieving are acceptable, that is, the training they receive brings them closer to achieving the professional profile that the institution expects of them.

Table 3: Social climate vs. Development of professional performance competencies in initial education students of the Higher Public Pedagogical Institute of Huaraz.

\begin{tabular}{lcccc}
\hline & \multicolumn{3}{c}{ Development of } & \\
& Professional Competences & \multirow{2}{*}{ Total } \\
\cline { 2 - 4 } & Low & Medium & High & \\
\hline Low & $11.1 \%$ & $4.8 \%$ & $0.8 \%$ & $16.7 \%$ \\
Medium & $2.4 \%$ & $60.3 \%$ & $4.0 \%$ & $66.7 \%$ \\
High & $0 \%$ & $7.9 \%$ & $8.7 \%$ & $16.7 \%$ \\
\hline \multicolumn{1}{c}{ Total } & $13.5 \%$ & $73.0 \%$ & $13.5 \%$ & $100.0 \%$ \\
\hline
\end{tabular}

Table 4: Chi-square test results with SPSS

\begin{tabular}{ccccc}
\hline & Operation & Table value $\left(\mathrm{X}^{2}\right.$ & \multicolumn{2}{c}{ Interpretation } \\
\cline { 4 - 5 } & value $\left(\mathrm{X}^{2}\right)$ & $0.05,4)$ & $\mathrm{X}^{2}<\mathrm{X}^{2} 0.05,4$ & $\mathrm{X}^{2}>\mathrm{X}^{2} 0.05,4$ \\
\hline $\begin{array}{c}\text { Square } \\
\text { Chi }\end{array}$ & 92.279 & 9.49 & & Yes \\
\hline
\end{tabular}

Students as social beings interact in various social spaces from childhood to adulthood, in family, neighborhood, friend and professional settings. Unlike other professions, it is essential for initial training teachers to know how to establish relationships in a pleasant way, encouraging a suitable climate for the learning process by teaching by example. Being social skills an aspect of daily life, it is necessary to know them in order to change them and to know, conclusively, how to do it.

The status and prestige of the teaching profession and of those who practice it are subject to the trends, demands and perspectives of the social, political, economic and cultural processes of the context. Hence, the teaching professions change their perspectives, their technology and their value for the purposes of these processes that demand adjustments. Today the country and the 


\section{GMS \\ Journal of Global Management Sciences}

Vol. 4, $\mathrm{N}^{\circ}$ 1, 2021
Copyright @ 2021, CINCADER.

ISSN 2663-0753

DOI: https://doi.org/10.32829/gms.v4i1.208

world request that the training of the initial education educator be repositioned in the permutations that have been taking place.

At the time, the management of the social climate in the classroom is essential, it refers to the link between attitudes towards the institution, the classroom, the pedagogical tasks that the agents of the class generate and that in their entirety institute a state of human correlation. As Barrientos (2016) expresses the relationship that exists between participatory communication between classroom members and the expert's ability to promote thought and language experiences, both sensible and unstable, creating questions and perpetrating renewed tasks in the classroom, with the intention to elicit learning, judgment, deliberation, and the advantage of a richer and more multiple lexicon. To bring about lasting changes in the identity, knowledge and practice of the teaching profession, we have to achieve cohesion around the formation of a new approach to teaching that integrates the new generations of male and female teachers in a leading way. An initial teacher training relevant to social changes.

The need for interaction between teachers and students is important today, however, it has not always been understood in this way. The need for the teacher to gain skills to bond more closely with their students as people must be recognized, and not concentrate solely on cognitive aspects. This corresponds to saying, in the current language, competence-based education, where the teacher must externalize competences to agree affective and cognitive aspects, as the present research focuses.

\section{Conclusions}

- Given that the value of the square chi is $\mathrm{X} 2=92.279, \mathrm{GL}=4$ and $\mathrm{p}=0.000$, it is greater than 9.49 , therefore, it is affirmed that the social climate in the classroom is propitiously related to the development of professional skills in teacher initial training students.

- The peculiarities of the social climate in students of the initial teaching career imply extensions concerning the relationships, organization, growth in the institutional educational community that benefit the examination of a comprehensive professional training and efficient performance.

- The development of professional competencies in students of the initial education professional career involves extensions of personal, pedagogical and social-community training, areas in which students find opportunities to develop and strengthen skills necessary for their professional training.

\section{References}

Barrientos, A. 2016. Habilidades sociales y emocionales del profesorado de educación infantil relacionadas con la gestión del clima de aula. http://eprints.ucm.es/40450/1/T38117.pdf

Becerra, S. 2006. ¿Cómo podemos intervenir para fortalecer el clima educativo en tiempos de innovación? Estudios pedagógicos (Valdivia), 32(2), 47-71. https://dx.doi.org/10.4067/S0718-07052006000200003

Cere. 1993. Evaluar el contexto educativo. Documento de Estudio. Vitoria: Ministerio de Educación y Cultura, Gobierno Vasco.

Márquez, M. 2004. Clima social y autoeficacia percibida en estudiantes inmigrantes una propuesta intercultural. https://eprints.ucm.es/5354/1/T28025.pdf 
Vol. 4, $\mathrm{N}^{\circ}$ 1, 2021

\section{Journal of Global \\ Management Sciences}

Copyright @ 2021, CINCADER.

ISSN 2663-0753

DOI: https://doi.org/10.32829/gms.v4i1.208
A publication of

\section{CINGADER}

Centre of Research and Training for

Regional Development

Online at www.journals.cincader.org

Mas, O. 2011. El profesor universitario: sus competencias y formación. http://www.redalyc.org/pdf/567/56722230013.pdf

Pavié. A. 2011. Formación docente: hacia una definición del concepto de competencia profesional docente. http://www.redalyc.org/pdf/2170/217017192006.pdf

Pereira, P. 2010. Las dinámicas interactivas en el ámbito universitario: el clima de aula. División de Educación Básica del Centro de Investigación y Docencia en Educación (CIDE), Universidad Nacional Heredia, Costa Rica. http://www.redalyc.org/pdf/1941/194115343002.pdf

Ríos, D.; Bozo, N.; Marchant, J. y Fernández, P. 2010, Factores que inciden en el clima de aula universitario Revista Latinoamericana de Estudios Educativos (México), vol. XL, núm. 3-4, pp. 105-126

Tejada, J. 2009. Competencias docentes. Profesorado. Revista de curriculum y formación del profesorado. Grupo CIFO. Universidad Autónoma de Barcelona. https://recyt.fecyt.es/index.php/profesorado/article/view/42339/24279 